\title{
KONSEP KHALIFATULLAHU FIL ARDL: DEKONSTRUKSI CORPORATE SOCIAL RESPONSIBILITY
}

\author{
Wulan Retnowati ${ }^{1)}$, Roza Mulyadi $^{2}$ \\ Universitas Sultan Ageng Tirtayasa, Serang, Banten \\ naulsmart@yahoo.co.id
}

\begin{abstract}
The purpose of this research is to deconstruct the concept of corporate social responsibility that has failed in practice. Because there are still many tendency of company practices that only have the character of ceremonial course and aim to abort the obligation and the emergence of environmental destruction practices by companies that have implemented corporate social responsibility. This research used the concept khalifatullahufilardl, in Islam it is meansthathe human function on earth as the ruler of the universe. By deconstructing the concept of corporate social responsibility that only refers to the singgle bottom line that focus on God SWT as stakeholders, the concept khalifatullahufilardl can be applied in changing the paradigm of corporate social responsibility so that ultimately the practice of corporate social responsibility will be more aware on sustainable development and ultimately can increase corporate profits that will have an impact on increasing mutual prosperity (between companies and surrounding communities).
\end{abstract}

Keywords: corporate social responsibility, khalifatullahufilardl, ruler of the universe

\begin{abstract}
Abstrak
Tujuan dari makalah ini adalah untuk mendekonstruksi konsepcorporate social responsibility yang telah gagal dalam prakteknya. Karena masih banyaknya kecenderungan praktek-praktek perusahaan yang hanya bersifat seremonial saja dan bertujuan menggugurkan kewajiban serta munculnya praktek-praktek perusakan lingkungan oleh perusahaan yang telah melaksanakan corporate social responsibility. Makalah ini menggunakan konsep khalifatullahu fil ardldalam islam yaitu fungsi manusia di bumi sebagai penguasa alam semesta. Dengan melakukan dekonstruksi pada konsepcorporate social responsibility yang hanya mengacu pada singgle bottom line yaitu fokus pada Allah SWT sebagai pemangku kepentingan, maka konsep khalifatullahu fil ardl dapat diterapkan dalam mengubah paradigma corporate social responsibility sehingga pada akhirnya praktek corporate social responsibility akan lebih berkesadaran pada pembangunan berkelanjutan serta pada akhirnya dapat meninggkatkan keuntungan perusahaan yang akan membawa dampak pada peningkatan kemakmuran bersama ( antara perusahaan dan masyarakat sekitar)
\end{abstract}

Kata kunci: corporate social responsibility, khalifatullahu fil ardl, penguasa alam semesta 
IJVENTORY

Jurnal Akuntansi, Prodi. Akuntansi - FEB, UNIPMA, Vol. 1, No.2, April 2018

1. PENDAHULUAN

Setiap

perusahaan

mempunyai tujuan utama untuk

mempertahan kelangsungan

hidupnya. Agar kelangsumgan hidup

perusahaan dapat terjaga, perusahaan

dituntut untuk beroperasi secara

efisien, efektif dan ekonomis.

Sehingga perusahaan dapat

memperoleh laba yang pada

gilirannya perusahaan akan mampu

bertahan. Setiap kegiatan yang

dilakukan ditujukan untuk

memperoleh laba secara maksimum.

Sesuai konsep teori stakeholder

perusahaan juga mempunyai

tanggung jawab kepada para

pemangku kepentingan baik

eksternal maupun internal. Setiap

kegiatan perusahaan harus

mempertimbangkan para pemangku

kepentingan tersebut. Salah satu

pemangku kepentingan eksternal

adalah lingkungan dan masyarakat.

Sehingga harusnya perusahaan tidak

hanya mengejar laba maksimum

tetapi juga harus memperhitungkan

dampak kegiatan dalam rangka

mencari laba terhadap lingkungan

dan masyarakat sekitar. Sehingga

terjadi keseimbangan antara kebijakan perusahaan dengan

perilaku etisnya untuk beroperasi.

Salah satu implementasi tanggung jawab terhadap lingkungan dan masyarakat ini adalah melalui corporate social responsibility. Pemerintah Indonesia juga sudah mengatur kewajiban tersebut secara legal. Dan bagi perusahaan yang go public wajib melaporkan kegiatan corporate social responsibility dalam annual reportnya. Tapi yang menjadi masalah utama selama ini adalah implementasi corporate social responsibility. Banyak perusahaan melakukan praktek-praktek corporate social responsibility hanya sekedar menggugurkan kewajiban dari undang-undang tanpa memahami esensi corporate social responsibility. Sehingga implemantasi corporate social responsibility hanya pada kegiatan yang bersifat charity bukan pada kegiatan yang berdampak pada keberlangsungan lingkungan dan memberdayakan masyarakat sekitar. Hanya berupa sumbangansumbangan pada sekolah maupun pembangunan-pembangunan fisik seperti pembuatan jalan ataupun 
INVENTORY

Jurnal Akuntansi, Prodi. Akuntansi - FEB, UNIPMA, Vol. 1, No.2, April 2018

bangunan sekolah. Dan setelah Masalah kabut asap akibat

melakukan ini perusahan merasa pembakaran hutan ini telah sudah cukup dan merasa sudah membawa dampak yang sangat besar memenuhi kewajiban. Dan kembali beraktifitas yang normal.

Kasus asap di Kalimantan sudah merupakan kasus yang rutin terjadi di Indonesia. Kasus asap ini terjadi di setiap musim kemarau. Kabut asap menimpa kalimatan meninbulkan masalah dalam skala nasional yang rutin terjadi. Bahkan sampai ke Negara tetangga kita Malaysia, Brunei Darusalam dan Singapura. Negara kita pun sudah sering menerima kritikan dari maslah asap tersebut dari Negara tetangga. Namun pada kenyataannya masalah asap yang muncul akibat pembakaran hutan oleh oknumoknum korporasi tersebut tetap terjadi disetiap tahunnya. Masalah asap yang muncul terjadi ditengarai karena para korporasi pengusaha pengelolaan hutan melakukan pembakaran hutan dalam rangka pembukaan lahan hutan

(www.merdeka.com;

www.liputan6.com;

www.pekanbaru;tribunnews.com).

bagi warga di Kalimantan seperti di daerah Riau dan pekanbaru. Dampak asap tersebut tidak hanya berpengaruh pada kesehatan masyarakat tapi juga pada banyak bidang seperti misalnya pada jadwal penerbangan menuju ke Riau dan Pekanbaru bahkan juga penerbangan yang berasal dari daerah tersebut. Banyak yang mengalami penundaan yang tidak jelas serta pembatalan penerbangan karena jarak pandang yang tidak memenuhi standar penerbangan karena adanya kabut asap yang tebal. Belum lagi banyak sekolah yang terpaksa diliburkan. Dan masyarakat tidak bisa beraktifitas secara normal karena kabut asap yang sangat tebal. Bahakan kabut asap tersebut juga telah memakan korban berupa balita di Riau yang meninggal karena infeksi ISPA (www.tempo.co.id).

Kabut asap yang sudah menjadi langganan di Kalimantan ini ditengarai dilakukan oleh para perusahaan pengelolaan hutan yang membakar hutan untuk melakukam 
INVENTORY

Jurnal Akuntansi, Prodi. Akuntansi - FEB, UNIPMA, Vol. 1, No.2, April 2018

pembukaan lahan. Dan telah rangka maksimum profit melalui

diselidiki 7 perusahaan yang diduga

pembakaran hutan yang minimum

melakukan pembakaran hutan

cost. Dan hal ini benar untuk logika

tersebut (www.merdeka.com). Disisi

perusahaan tapi apakah ini perilaku

lain perusahaan yang diduga

yang etis? Dan disisi lain mereka

melakukan pembakaran hutan untuk

juga sudah melaksanakan kewajiban

membuka lahan tersebut ada juga

sosial sesuai peraturan. Dari sudut yang merupakan perusahaan pandang perusahaan pembakaran korporasi yang besar. Dimana perusahaan tersebut juga telah melaksanakan kewajiban corporate social aresponsibility. Mereka melakukan kewajiban corporate social responsibility dengan memberikan sumbangan pada masyarakat sekitar dengan memberikan batuan pada sekolahsekolah, perbaikan jalan dan pemberian beasiswa bagi anak yang kurang mampu. Dan untuk salah satu korporasi ayang diduga adalah perusahaan terbuka yang sudah terdaftar di bursa efek Indonesia. Sehingga dapat dilihat dalam annual reportnya bahwa perusahaan tersebut telah melakukan corporate social responsibility.

Jika dikaitkan dengan kasus pembakaran hutan yang terjadi di kalimantan, perusahaan sudah menjalan prinsip ekonomi dalam hutan untuk membuka lahan baru adalah tindakan yang tepat karena efisien, efektif dan ekonomis. Sedangkan implementasi corporate social responsibility melalui charity adalah tepat dan benar. Tetapi perusahaan melupakan esensi corporate social responsibility dan tanggung jawab perusahan pada lingkungan dan masyarakat (stakeholder eksternal).Karena esensi dari corporate social responsibility tidaklah hanya pada sekedar menggugurkan kewajiban saja tetapi lebih bermakna pada kewajiban secara menyeluruh terhadap tata kelola dan praktek bisnis yang menuju keseimbangan anatarpemenuhan keawjiban pada pemangku kepentingan internal dan eksternal. Yang pada kahirnya akan membawa dampak kesejahteraan 
INVENTORY

Jurnal Akuntansi, Prodi. Akuntansi - FEB, UNIPMA, Vol. 1, No.2, April 2018

dan menjaga ekosistem secara responsibility. Dan perusahaan-

keberlanjutan..

perusahaan tersebut sudah

Peraturan tentang tanggung

melaksanakannya. Tetapi mereka

jawab sosial juga telah dikeluarkan

tetap saja melaksanakan pembakaran

oleh pemerintah pada tahun 2007

yaitu UU R.I No. 40 tahun 2007

pasal 66 dan 74. Yang kemudian

dipertegas dengan dikeluarkannya

Peraturan Pemerintah (PP) Republik

Indonesia Nomor 47 Tahun 2012

tentang tanggung jawab sosial dan

lingkungan perseroan terbatas.

Menurut Pasal 66 ayat 2 PP no 47

Tahun 2012 , setiap perusahaan

diwajibkan membuat laporan

keuangan dan juga laporan mengenai

pelaksanaan tanggung jawab sosial

hutan untuk membuka lahan baru.

Atas dasar inilah maka tujuan dari

artikel ini adalah ingin membangun

konsep corporate social

responsibility yang berkesadaran

dengan memasukkan konsep

khalifatullahu fil ardlyang

menerapkan tugas manusia sebagai

penguasa alam semesta.

\section{EKOLOGI SEBAGAI \\ PARADIGMA BARU}

Ernst Haeckel adalah orang dan lingkungan. Selain itu kewajiban mengenai tanggung jawab sosial juga diatur dalam Undang - Undang Perseroan Terbatas berisi tentang perseroan pasal 74 ayat (1).

Hal ini memunculkan pertanyaan : apa yang salah dengan corporate social responsibility?

Mengapa kasus pembakaran hutan untuk membuka lahan baru tetap terjadi? Hal ini menjadi menarik untuk dikaji karena di Indonesia sendiri sudah ada kewajiban tentang pelaksanaancorporate social yang pertama kali memperkenalkan istilah ekologi. Kata ekologi berasal dari bahasa Yunani oikos yang berarti rumah atau tempat tinggal dan logos yang berarti ilmu. Sehingga ekologi bisa dimaknai juga sebagai ilmu yang mempelajari tentang organisme-organisme dalam tempat tinggalnya (Odum, 1971). Ekologi juga bisa diartikan sebagai ilmu tentang rumah tangga makhluk hidup (Soemarwoto, 1997).

Dalam ekologi kita juga mempelajari tentang konsep dari 
INVENTORY

Jurnal Akuntansi, Prodi. Akuntansi - FEB, UNIPMA, Vol. 1, No.2, April 2018

ekosistem, yang merupakan salah

sepanjang sejarah manusia.

satu kajian utama dalam ekologi.

(Rasmussen dalam Tucker dan Grim,

Ekosistem dapat diartikan sebagai

2003). Kattsoff menyatakan hal

sinergi mahluk hidup dengan

tersebut sebagai konsep tentang alam

lingkungannya sehingga membentuk

yang sering dikenal sebagai sebagai

suatu sistem ekologis (Soemarwoto,

1997; Odum, 1971). Menurut capra,

kosmologi (Kattsoff, 2004).

Konsep ekologi sebagai

terdapat empat elemen dasar dalam

ekologiyaitu sistem, siklus,

kemitraan/sinergi, keragaman, dan

keseimbangan dinamis (Capra,

2005). Ke empat prispis dasar tadi

saling terkait dengan menjalankan

aktifitasnya, saling berhubungan

dengan saling menguntungkan

dengan secara alamaiah. Tanpa salah

satu prinsip tersebut maka ekosistem

tidak bisa berjalan yang pada

akhirnya akan menimbulkan

kematian dalam ekosistem tersebut.

Suatu konsep dimana kita

sebagai manusia melihat duania dan

alam semesta di sekeliling kita dan

bagaimana kita berhubungan secara

sinergisndengan alam, biasa disebut

dengan pandangan dunia(Witteveen,

2004). Manusia hidup dan belajar

dari alam dan kemudian manusia

menciptakan konsep-konsep tentang

alam dan membentuknya menjadi

budaya-budaya baru yang berbeda

pandangan dunia, pertama kali didengungkan oleh Thomas Bery. Pandangan dunia ekologis adalah sebagai suatu pandangan tentang system yang terintegrasi antara unsur-unsur didalam (termasuk juga manusia) yang bersinergi untuk mencapai keseombangan yang dinamis. Konsep ini kemudian menjadi paradigm baru yang telah mebawa angina perubahan dalam berbagai bidang ilmu hingga sistem politik, tehnologi, termasuk juga dalam ilmu ekonomi.

Didalam ilmu ekonomi, perubahan paradigma tersebut telah memunculkan pandangan baru dalam teori teori stakeholder. Dimana dalam teori ini, perusahaan juga mempunyai tanggung jawab kepada para pemangku kepentingan baik eksternal maupun internal. Salah satu pemangku kepentingan eksternal ini adalah lingkungan atau alam. Dalam 
INVENTORY

Jurnal Akuntansi, Prodi. Akuntansi-FEB, UNIPMA, Vol. 1, No.2, April 2018

konteks paradigma ekologi ini, maka teori stakeholder juga harus bisa menunjukkan keberpihakan dan mengimplementasikan paradigma ekologi tersebut.

Pengimplementasian tersebut tercermin dalam semua kebijakan dalam operasi perusahaan. Bahwa perusahaan dalam menjalankan aktifitas usahanya untuk memperoleh laba maksimum juga tidak lepas kaitannya dengan alam sekitar. Sehingga perusahaan sebagai bagian dari sistem alam yang melingkupi usahanya, mempunyai tanggung jawab atas lingkungan/alam sekitasnya. Konsep inilah yang kemudian memunculkan konsep Corporate Social Responsibility

\section{CORPORATE SOCIAL} RESPONSIBILITY

\section{KonsepCorporate Social}

Responsibility (CSR) muncul akibat adanya kesadaran masyarakat dalam menyikapi dampak negatif dari aktifitas perusahaan terhadap lingkuangannya. Zaenudin menyatakan bahwa perusahan besar beroperasi lebih kompleks dan lebih luas sehingga memberikan pengaruh

yang lebih besar terhadap lingkungan dan masyarakat dimana perusahaan berdiri. Kondisi ini menimbulkan keprihatinan bagi para pemegang sahamnya mengenai program sosial yang dilaksanakan perusahaan dibandingkan perusahaan kecil. Dalam teori legitimasi juga disebutkan bahwa perusahaan harus bertindak bagi masyarakat dengan perilaku yang dapat diterima secara sosial yang dapat meningkatkan keberhasilan bisnis mereka (Suttipun \& Stanton, 2012).

Howard Bowen (1908-
1989) adalah seorang historian
ekonom Amerika yang
memberikaninspirasi
kemunculanakuntansisosialdanlingk
ungan.KontribusiBowen adalah
denganpublikasibukudenganjudul
SocialResponsibility of
Businessmentahun1953.Bowen(1953
)meletakandasarkonsepinidenganmen
gatakan:
-
totheobligationofbusinessmantopurs
uethosepolicies,to
makethosedecisions,ortofollow
thoselinesofactionwhichare
of 
INVENTORY

Jurnal Akuntansi, Prodi. Akuntansi-FEB, UNIPMA, Vol. 1, No.2, April 2018

desirableinterms oftheobjectives

andvalues ofour society.

Kemudiansecarakolektifdijad

ikanlandasanawalmendefinisikan

tanggungjawabsosialbagi kewajiban

pelakubisnisuntukmenetapkan

tujuanbisnisyangselarasdengan

tujuan (objectives) dannilai-

nilaimasyarakat(Societyvalues).Selan

jutnya, konsep Bowen dipertajam

dengan keith Davis dalam bukunya:

"CanBusinessAffordtoIgnoreitsSocia

1Responsibilities?”.

Davismenegaskanadanyatanggungja

wabsosialorganisasidi

luartanggungjawabekonomisemata.

Pada tahun 1971

CommitteeforEconomicDevelopme

nt (CED) memperkenalkan penyusunan lapoan perusahaan dengan konsep

threeconcentriccircles.

Carroll(1979)

menjelaskankomponen-

komponentanggungjawabsosialorg

anisasibisnis

kedalamempatkategori,yaitu:

1) Economicresponsibilities, $\tan$ ggungjawabsosialpadakatego

riiniberlandaskanbahwamotif

profitadalahmotif utamadalammembangunorga

nisasibisnis. Organisasibisnis

padadasarnyaadalahtanggung

jawabekonomikarenalembaga

bisnis terdiriatas aktivitas

ekonomiyangmenghasilkanba

rangdanjasabagimasyarakatya

ngmenguntungkan.

2) Legalresponsibilities, tanggun gjawaborganisasidalmmenjal ankanbisnisyaitudenganmena ati hukumdan peraturanyangberlakudimana hukumdan peraturan tersebutpada hakikatnya dibuatolehmasyarakatmelaluil embagalegislatif.Tanggungja wablegalini adalahkoridordansistemuntuk mengaturorganisasidalamber bisnis.

3) Ethicalresponsibilities, organi sasidiharapkanmenjalankan bisnisnyasecaraetisdannorma moral masyarakat.Masingmasingpihakdalammenjalank anbisnisdiaturstandar, etika,normaagarmasingmasingpuas dalamberbisnis.

4) Discretionary

Responsibilities, Masyarakat 
IJVENTORY

Jurnal Akuntansi, Prodi. Akuntansi - FEB, UNIPMA, Vol. 1, No.2, April 2018

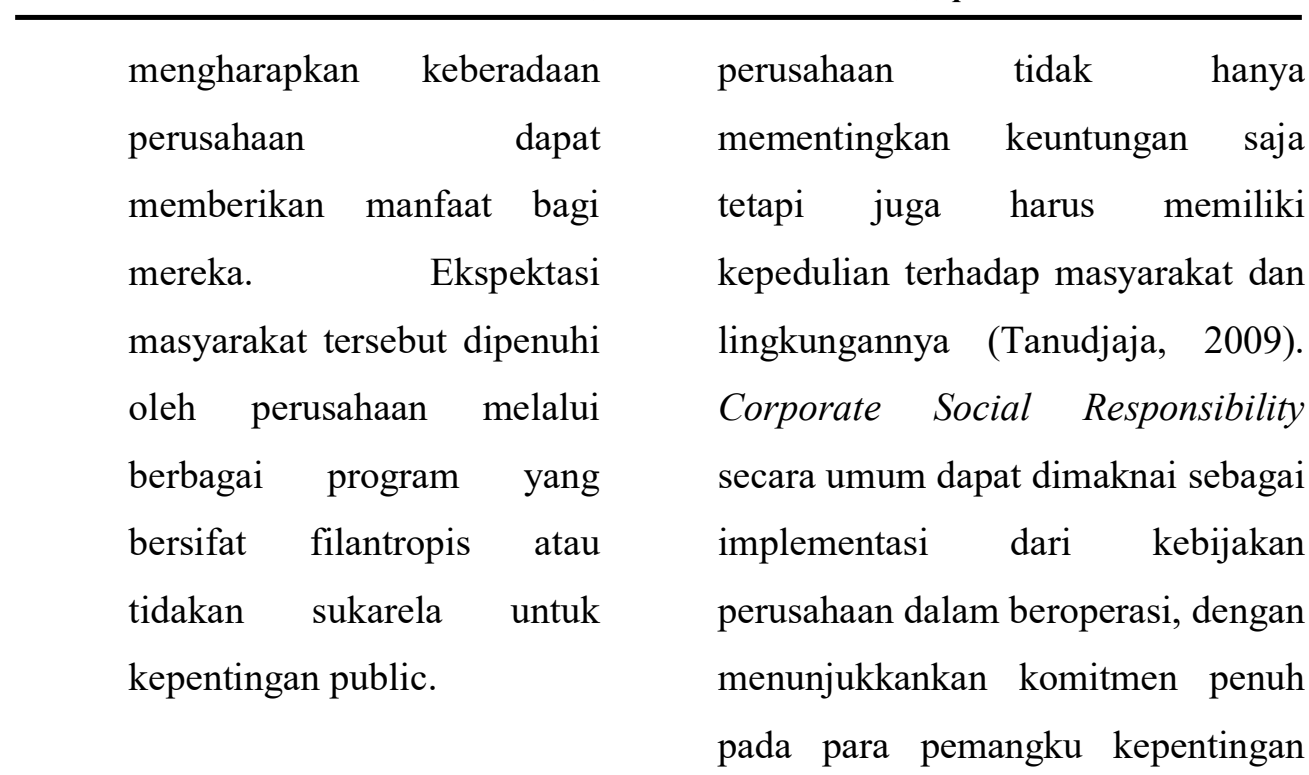

\begin{tabular}{lr}
\multicolumn{1}{c}{ Elkington (1997) } & adalah \\
peletak dasar konsep triple & bottom \\
line. & Konsep \\
inimemberikaninspirasilebihseriusten \\
tangperluasan
\end{tabular}

akuntansikonvensionalyangsinglebot

tom line, yaitukeuangan saja.Istilah

TripleBottomLinemenjadipentingsaat

people,planetdan

profitditawarkanmenjadikonsepakunt

ansipertanggungjawabansosialdanlin

gkungan.

Corporate Social

Responsibility atau tanggung jawab sosial perusahaan merupakan tanggung jawab perusahaan yang harus berpijak pada tiga prinsip dasar yang dikenal dengan Triple Bottom Lines, yaitu profit, people dan planet, yang berarti bahwa (termasuk pada masyarakat dan lingkungan) dan turut berpartisipasi secara nyata dalam pembangunan secara berkelanjutan (Wardani, 2013).

Pada tahun 1999 World Business Council for Sustainable Development (WBCSD) sebagai salah satu organisasi non profit yang juga sangat fokus pada pembangunan yang berkelanjutan, juga telah memberikan definisi dari Corporate Social Responsibility sebagai komitmen bisnis untuk turut berperanserta dalam pembangunan untuk meningkatkan kualitas hidup tenaga kerja, keluarga, komunitas lokal dan masyarakat luas. Tanggung jawab sosial perusahaan sering dianggap sebagai respon terhadap 
INVENTORY

Jurnal Akuntansi, Prodi. Akuntansi - FEB, UNIPMA, Vol. 1, No.2, April 2018

tekanan dari pihak luar atau sebagai upaya pro - aktif untuk mencegah bahkan mengurangi tekanan tersebut dan meningkatkan reputasi serta nilai perusahaan. Commission of the European Communities tahun 2001 juga mendefinisikan Corporate Social Responsibility sebagai praktek dimana kepedulian sosial dan lingkungan perusahaan diintegrasikan dalam kebijakanoperasi bisnis mereka dan dalam berinteraksi dengan para pemangku kepentingan secara sukarela (Ebiringa et al, 2013).

Dari pengertian diatas dapat disimpulkan bahwa Corporate Social Responsibility atau tanggung jawab sosial perusahaan merupakan bagian terpenting dalam strategi perusahaan karena dengan adanya tanggung jawab sosial perusahaan, mencerminkan bahwa suatu perusahaan tidak hanya memikirkan keuntugan tetapi juga mencakup berbagai kegiatan sosial, ekonomi serta bagaimana berinteraksi dengan karyawan, pemasok, pelanggan dan masyarakat dimana perusahaan beroperasi serta sejauh mana perusahaan berusaha untuk menjaga dan melindungi lingkungan.

$$
\text { Corporate Social }
$$

Responsibility atau tanggung jawab sosial perusahaan merupakan tanggung jawab perusahaan yang harus berpijak pada tiga prinsip dasar yang dikenal dengan Triple Bottom Lines, yaitu profit, people dan planet, yang berarti bahwa perusahaan tidak hanya mementingkan keuntungan saja tetapi juga harus memiliki kepedulian terhadap masyarakat dan lingkungannya (Tanudjaja, 2009)

\section{5) PANDANGAN ISLAM TENTANG PERAN DAN FUNGSI MANUSIA}

Dalam Q.S At Tiin, disebutkan bahwa Allah telah menciptakan manusia dalam keadaan paling baik. Allah menciptaka manusia dengan segala kelebihannya. Hal ini sesuai dengan tujuan penciptaan manusia oleh Allah. Sehingga manusia dibekali dengan alat-alat yang sempurna seperti akal dan pikiran. Dengan alat yang sempunra tadi maka manusia diharapkan akan mampu 
menjalankan tujuan penciptaan jelas daan tercantum dalam dalam manusia.Tujuan penciptaan manusia Q.S Al Baqarah 2:30:

telah ditunjukkan ole Allah secara

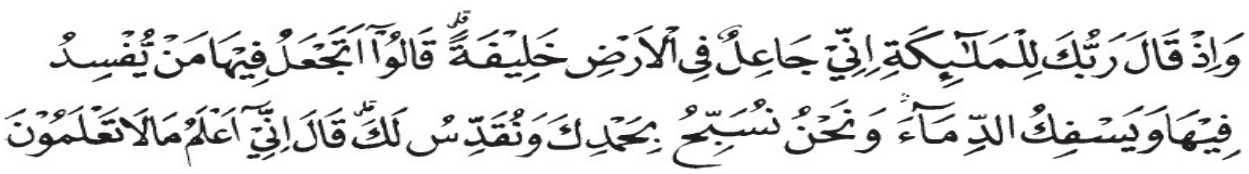

Yang artinya adalah: "Dan ingatlah menumpahkan darah padanya, ketika Rabbmu berfirman kepaada padahal kami senantiasa bertasbih malaikat, "Sesungguhnya Aku dengan memuji dan mensucikan hendak menjadikan khalifah di muka Engkau?" Rabb berfirman, bumi." Mereka berkata,"Mengapa "Sesungguhnya aku lebih Engkau hendak menjadikan khalifah mengetahui yang tidak kamu di muka bumi itu orang yang akan ketahui”. membuat kerusakan dan

Serta Q.S Adz Dzariyat 51:56 :

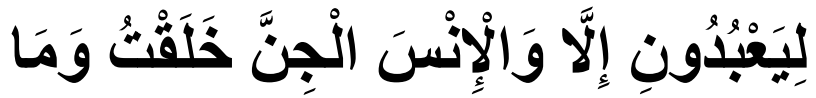

Yang artinya :

"Dan aku tidak menciptakan jin dan manusia melainkan supaya mereka beribadah kepadaKu"

Kedua ayat ini menjadi kisah penciptaan manusia juga disebutkan pembuka keberadaan dan eksistensi dalam QS Al-An'am 165:

manusia di muka bumi ini. Selain kedua ayat tersebut, tujuan 


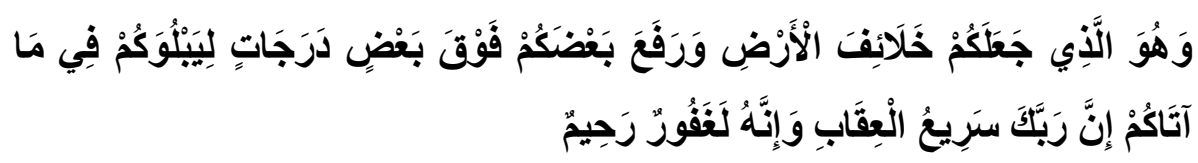

Yang artinya:" Dan Dialah yang menjadikan kamu penguasa-penguasa di bumi dan Dia meninggikan sebahagian kamu atas sebahagian (yang lain) beberapa derajat, untuk mengujimu tentang apa yang diberikan-Nya kepadamu. Sesungguhnya Tuhanmu amat cepat siksaan-Nya, dan sesungguhnya Dia Maha Pengampun lagi Maha Penyayang”

$\begin{array}{ll}\text { Dari ketiga ayat tersebut } & \text { Hakikatnya, khilafah adalah } \\ \text { secara jelas telah menunjukan } & \text { manusia bukan pemilik, apalagi } \\ \text { tujuan penciptaan manusia yaitu } & \text { penguasa, segala yang ada di atas } \\ \text { sebagai khalifatullahu fil ardl } & \text { bumi, namun hanya sebagai } \\ \text { (pemelihara alam semesta), } & \text { wakil dari Allah yang akan } \\ \text { warosatul anbiya'dan sebagai } & \text { menjalankan tugasnya secara } \\ \text { abdullah (hamba Allah SWT). Ketiga } & \text { bertanggung jawab (Al Maududi, } \\ \text { tujuan tersebut merupakan suatu } & \text { 1994; Machasin dalam Aminah } \\ \text { kesatuan yang tidak dapat } & \text { dkk, 2005). Sehingga dapat } \\ \text { dipisahkan. Agar manusia mampu } & \text { disimpulkan bahwa Pengertian } \\ \text { menjalankan tugasnya sebagai } & \text { khalifah disini adalah penguasa } \\ \text { Khalifatullah, Warosatul Anbiya dan } & \text { atau pengganti Allah yang } \\ \text { Abdullah dengan sebaik-baiknya, } & \text { mengatur segala sesuatu yang } \\ \text { Allah SWT memberikan anugrah } & \text { terkandung di bumi, agar bisa } \\ \text { kepada manusia berupa panca indra, } & \text { dimanfaatkan untuk kepentingan } \\ \text { akal, nafsu dan qalbu (Tafsir, 2012). } & \text { umat manusia } \\ \text { Secara umum fungsi penciptaan } & \text { bertanggung jawab. } \\ \text { manusia dapat diklasifikasikan } & \text { Peran manusia sebagai khalifah } \\ \text { menjadi tiga yaitu: } & \text { di muka bumi ini akan melekat } \\ \text { 1) Manusia sebagai Khalifah } & \text { pada diri manusia dan harus } \\ \text { Allah di muka bumi. } & \text { Peran ini memberikan fungsi }\end{array}$


bagi umat manusia untuk menjalankan hidupnya untuk:

a. Memakmurkan Bumi (al'imarah)

Fungsi kalifah disini adalah bertugas sebagai alat untuk memakmurkan bumi dengan melakukan pembanguananpembangunan di bumi, dengan cara memanfaatkan sumber daya yang alam yang telah diciptakan oleh Allah sesuai kaidah dan aturan yang tercantum dalam Al Qur'an dan As sunnah (hadist Nabi)

b. Memelihara Bumi (arri'ayah) Dalam konteks arri'ayah, manusia mempunyai tugas dan fungsi untuk menjaga alam semesta , mencegah perusakan alam serta untuk menjalankan fungsi tersebut manusia ahrus dilandasi oleh akidah yang baik yaitu akhlakulkarimah.

c. Perlindungan

Fungsi terakhir dari manusia adalah perlindungan. Fungsi ini mengandung makana bhwa manusia harus bisa melindungi alam Khalifah memiliki semesta dengan mengimplementasikan perlindungan pada lima pokok sendi kehidupan yaitu agama (aqidah), jiwa manusia, harta kekayaan,akal pikiran, dan keturunan (kehormatan).

\section{2) Manusia sebagai Warosatul} Anbiya (Penyampai Kebenaran Allah SWT)

Kehadiran Nabi Muhammad saw. di muka bumi ini mengemban misi besar yang akan menunjukkan bahwa islam sebagai agama yang 'Rahmatal lil 'Alamiin'. Bahwa agama islam adalah jalan yang akan membawa semua umat manusia dan seluruh alam semesta untuk tunduk patuh pada syari'atsyari'at dan hukum-hukum Allah SWT demi tercapainya keselamatan dunia akhirat. Umat islam sebagi umat dari Nabi besar Muhammad saw juga mempunyai tugas yang sama yaitu sebagi penyampai kebenaran dari Allah SWT seperti yang ercantum dalam $\mathrm{Al}$ Qur'an, untuk mengajak 
INVENTORY

Jurnal Akuntansi, Prodi. Akuntansi - FEB, UNIPMA, Vol. 1, No.2, April 2018

semasam manusia menuju jalan

kebenaran dalam koridor syariah islam untuk mencapai keselamatan dan kebahagiaan dunia dan akherat. Untuk mencapai keselamatan dunia akherat, maka manusia dalam berkehidupan harus berpijakkan pada tiga kerangka dasar hubungan manusia, yaitu:

a. Hubungan manusia dengan Tuhan, Sang Pencipta (habblum Minaallah)

b. Hubungan manusia dengan manusia lain dalam kehidupan bermasyarakat (hablum Minannas)

c. Hubungan manusia dengan alam sekitarnya

\section{3) Manusia sebagai 'Abd} (Pengabdi Allah)

Dalam fungsi yang ketiga ini, lebih menekankan pada fungsi manusia secara individu yatu fungsi manusia sebagai hamba Allah yang harus tunduk patuh pada perintah Allah SWT. Dengan menjalankan semua perintah-Nya serta menjauhi segala laranganNya, seperti yang tercantum dalam Al Qur'an dan sunnah rasul. Secara luas konsep 'abd ini meliputi seluruh aktivitas manusia dalam kehidupannya. Bahwa manusia hidup hanyalah untuk beribadah dan mendapatkan ridha Allah SWT.

\section{KONSEP}

KHALIFATULLAHU FIL

ARDL SEBAGAI

PANDANGAN EKOLOGIS

DUNIA YANG MENDASARI

CORPORATE SOCIAL RESPONSIBILITY

Mengacu pada penjelasan pada bagian-bagian sebelumnya, maka penulis akan mencoba membuat suatu paradigam baru dalam konsep ekologis sebagai pandangan dunia dengan mendasarkan pada konsep Khalifatullahu Fil Ardldalam perspektif Islam.Suatu para digma baru dalam pandangan dunia mengenai ekologis yang berisikan cara pandang dan cara berpikir umat Islam terhadap lingkungan yang akan membawa cara pandang dunia yang baru dengan memberikan ruang luas bagi pengimplementasian pada 
INVENTORY

Jurnal Akuntansi, Prodi. Akuntansi - FEB, UNIPMA, Vol. 1, No.2, April 2018

pembangunan lingkungan yang menyatakan bahwa Tuhan tidak

berkelanjutan. Suatu cara pandang berkuasa atas alam semesta yang

yang diharapkan dapat memberi telah Dia ciptakn. Hal inilah yang

sumbangan ideologis bagi Corporate menjadi point utama perbedaan

Social Responsibility yang pandangan antara Islam dengan

bersandarkan pada ajaran Islam. sekuler. Dalam agama Islam percaya

Penekanan utama atas dan yakin bahwa Allah SWT adalah

dekonstruksi ini adalah berlandaskan pencipta alam semesta dan pengasa

pada pemahaman awal tentang alam

semesta. Bahwa Allah SWT adalah

penguasa tunggal serta penguasa

sejati dari alam semesta. Karena

Allah SWT adalah pencipta alam

semesta dan Ia memiliki dan

menguasai secara penuh atas semua

ciptaan_Nya. Banyak agama yang

ada di dunia juga menimbulkan

banyaknya penafsiran yang berbeda

mengenai bagaimana penciptaan

alam semestas serta bagaimana kuasa

Sang Pencipta atas ciptaan_Nya.

Namun semua pandangan dalam

agama juga telah menunjukkan suatu

pandangan yang sama yaitu bahwa

Tuhan lah yang menciptakan alam

semesta dan Dia berkuasa atas

ciptaannya. Demikian halnya bagi

para kaum sekuler. Kaum sekuler

juga meyakini bahwa alam

diciptakan oleh Tuhan, bukan oleh

manusia. Namun kaum sekuler

atas segala ciptaan-Nya. Hal ini

menimbulkan konskuensi pada pengakuan tentang kepemilikan segala sesuatu di alam ada pada Tuhan, manusia tidak mempunyai hak kepemilikan sedikitpun atas alam sebagaimana dijelaskan oleh al Maududi (1994).

Dalam konsep ekologis, terdapat ekosistem. Ekosistem dapat diartikan sebagai sinergi mahluk hidup dengan lingkungannya sehingga membentuk suatu sistem ekologis (Soemarwoto, 1997; Odum, 1971). Menurut capra, terdapat empat elemen dasar dalam ekologi yaitu sistem, siklus, kemitraan/sinergi, keragaman, dan keseimbangan dinamis (Capra, 2005). Ke empat prispis dasar tadi saling terkait dengan menjalankan aktifitasnya, saling berhubungan dengan saling menguntungkan 
INVENTORY

Jurnal Akuntansi, Prodi. Akuntansi - FEB, UNIPMA, Vol. 1, No.2, April 2018

dengan secara alamaiah. Tanpa salah

satu prinsip tersebut maka ekosistem

tidak bisa berjalan yang pada

akhirnya akan menimbulkan

kematian dalam ekosistem tersebut.

Manusia adalah salah satu bagian

dari ekosistem. Dia hidup,

berkembang dan meninggal.

Karenanya manusia tidak bisa

dipisahkan dalam ekossistem karena

manusia adalah bagian ekosistem itu

sendiri. Manusia, sebagai mahluk

ciptaan Tuhan, hidup bersama

dengan mahluk ciptaan Allah SWT

yang lainnya, adalah bagian tak

terpisahkan dalam ekosistem yang

bersifat kompleks dari sistem ekologi

alam. Untuk hidup manusia perlu

oksigen. Oksigen diproduksi oleh

tanaman di alam. Jadi manusia juga

merupakan bagian dari siklus

produksi oksigen dialam. Manusia

adalah bagian dari system alam,

siklus kehidupan dalam alam,

memnfaatakan system energy yang

dimunculkan oleh alam. Jadi

manusia sangatlah tergantung dengan

alam serta alam juga sangat

tergantung pada manusia.

Dalam pandangan Islam, manusia diciptakan dengan tujuan yang penting. Tujuan penciptaan

manusia yaitu sebagai khalifatullahu fil ardl (pemelihara alam semesta), warosatul anbiya (Penyampai Kebenaran Allah SWT) dan sebagai abdullah (hamba Allah SWT). Ketiga tujuan tersebut merupakan suatu kesatuan yang tidak dapat dipisahkan. Namun dalam konteks yang berhubungan dengan paradigmaekologis, tujun manusia adalah sebagai khalifatullahu fil ardl. Secara tegas bahwa manusia adalah wakil Allah SWT di dunia, manusia adalah pengemban jabatan sebagai pelaksana amanah dari Allah SWT. (Machasin dalam Aminah dkk, 2005). Manusia adalah pengganti Tuhan di bumi dalam melaksanakan kehendak-kehendak-Nya dan ketetapan-ketetapan-Nya (Shihab, 2005). Dimana hal ini membawa konskuensi bagi manusia untuk mengelola bumi seisinya secara baik demi kemakmuran umat manusia di bumi. Diman untuk menjalankan fungsi ini juga tidak bisa dilepaskan dari tujuan penciptaan manusia yang kedua dan ketiga yaitu sebagai warosatul anbiya dan sebagai abdullah. Sehingga hakekatnya 
IJVENTORY

Jurnal Akuntansi, Prodi. Akuntansi - FEB, UNIPMA, Vol. 1, No.2, April 2018

manusia adalah kaliffah di muka

bumi diman dalam menjalankan tugasnya manusia harus

berlandaskan pada Al qur'an dan sunnah serta bekerja dengan berniatkankan pada ibadah dan mengharapkan ridha Allah SWT.

Kepercayaan pada konsep manusia sebagai khalifah di bumi juga membawa implikasi rasa tanggung jawab karena dalam ajaran Islam setiap pemegang amanah akan diminta pertanggungjawabannya. Manusia diciptakan dengan berbagai sarana yang menjadi pembeda utama dengan ciptaan Allah yang lain. Dimana sarana-sarana tersebut merupakan kelebihan utama manusia. Sarana-sarana tersebut adalah akal pikiran, kebebasan berkehendak dan kemampuan spiritual yang merupakan perwujudan dari kuasa Allah SWT.

Dengan akal pikiran, manusia mampu berpikir secara kritis, mampu memenghasilkan ide-ide brilian yang dapat digunakan sebagai penciptaan alat, system, ilmu pengethauan, praktek-praktek bahkan tehnologi baru sebagai alat untuk menjalankan tugasnya untuk memanfaatkan alam semesta. Dengan kemampuan berpikirnya, manusia merupakan mahluk yang paling adaptif. Dia mampu menyesuaikan diri dengan segala kondisi di alam dan mampu benghadapi segala kesulitan hidup dan mampu membuktikan diri sebagai mahluk yang dapat bertahan sampai sekarang dengan memanfaatkan alam sekitarnya. Karena kemampuan itulah maka manusia menduduki tingkat tertinggi dalam piramida makanan di alam semesta.

Berbeda dengan ciptaan lain, manusia mempunyai peran yang sangat dominan dalam sistem ekologi alam. Hal ini terjadi karena manusia juga memanfaatkan alam untuk menunjang hidupnya tetapi manusia juga berfungsi sebagai penjaga alam yang dapat menentukan kelangsungan hidup alam. Hal ini merupakan akibat dari sifat kebebasan berkehendak yang telah diberikan kepada manusia oleh Tuhan. Manusia bebas untuk menjalankan kehendak pribadinya dengan melakukan pilihan-pilihan bagaimana dia menjalani hidupnya seperti dimana dia akan menetap, apa 
INVENTORY

Jurnal Akuntansi, Prodi. Akuntansi - FEB, UNIPMA, Vol. 1, No.2, April 2018

yang akan dia makan, siapa yang

alam secara maksimal dengan penuh

akan dipilih menjadi pendamping

pertanggung jawaban sebagai

hidupnya dan bagaimana dia akan

manifesti dari pemegang amanh dari

hidup. Pemilihan keputasan-

Allah SWT sehingga secara sadar

keputusasn itu ditentukan dan

maka manusia akan memanfaatkan

dilakukan oleh manusia itu sendiri

alam semesta dengan bijaksana demi

dengan menggunakan kemampuan

kemakmuran umat manusia dengan

berpikir. Kepemilikan akan

berladaskan ibadah dan ridha Allah

kemampuan berpikir sangat

membantu manusia dalam

SWT yang akan dipertanggung

jawabkan kepada Allah SWT.

menjalankan tugasnya yang sebagai

khalifah, dituntut untuk dapat

menjalankan amanat yang

diembannya. Manusia dituntut

menjadi khalifah dalam artian

sebagai "roh" yang membawa

kehidupan bagi seluruh alam, bukan

menjadi virus yang bersifat parasit

yang menggerogoti kelangsungan

alam. Hal ini perlu disadari

sepenuhnya karena setiap pembawa

amanat akan dimintai

pertanggungjawaban oleh Sang

Pemberi amanat.

Sehingga secara jelas konsep

Khalifatullahu Fil Ardl akan

membawa warna yang berbeda

dalam konsep ekologis dunia.

Konsep ini memunculkan keesadaran

tertinggi bagi manusia untuk

menggunakan atau memanfaatakan

Paradigma ekologis yang

baru dengan berlandaskan pada

konsep Khalifatullahu Fil Ardl juga

akan termanifestasikan juga dalam

teori teori stakeholder. Dimana

manusia sebagai pelaku bisnis juga

harus melaksanakan fungsi manusia sebagai kaliffah. Dimana bahwa dalam kaitan ini maka

manusia(melalui perusahaan) harus mampu memenuhi kepentingan para pemangku kepentingan tertinggi yaitu Allah SWT sebagai pemilik sejati alam semesta dan seluruh ciptaan-Nya. Yang pada akhirnya akan berimbas pada pemenuhan kepentingan pada level pemangku kepentingan yang lainnya yaitu pemangku kepentingan internal dan eksternal, yang tercermin pada kebijakan-kebijakan perusahaan 
IJVENTORY

Jurnal Akuntansi, Prodi. Akuntansi - FEB, UNIPMA, Vol. 1, No.2, April 2018

yang tidak hanya melulu mengejar

keuntungan semata tapi juga pada

praktek-praktek yang baik yang tidak

merugikan semua pihak.

Kesadaran yang muncul dari

teori stakeholder akan membawa

angin segar yang baru bagi dalan

konsep Corporate Social

Responsibility.Corporate Social

Responsibility atau tanggung jawab

sosial perusahaan merupakan

tanggung jawab perusahaan yang

harus berpijak pada tiga prinsip dasar

yang dikenal dengan Triple Bottom

Lines, yaitu profit, people dan

planet, yang berarti bahwa

perusahaan tidak hanya

mementingkan keuntungan saja

tetapi juga harus memiliki

kepedulian terhadap masyarakat dan

lingkungannya (Tanudjaja, 2009).

Dengan konsep Khalifatullahu Fil

Ardl maka perusahaan akam

mempunyai tanggung jawab utama

pada pemangku kepentingan

tertinggi yaitu Allah SWT. Tanggung

jawab sosial yang muncul dalam

konsep Corporate Social

Responsibility tidak hanya

berlandaskan pada triple bottom line

tetapi hanya merupakan single bottom line yaitu hanya pada Allah SWT sebagai pemangku kepentingan sejati dari umat manusia.

Dengan berfokuskan pada Allah SWT sebagai pemngku kepentingan tertinggi yang harus dipenuhi maka manusia sebagai pelaku bisnis dan yang mengendalikan perusahaan maka manusia juga harus menjalan fungsi manusia sebagai kaliffah di muka bumi. Kesadaran yang muncul tersebut akan merubah paradigma dalam mengelola perusahaannya. Kebijakan yang dibuat juga akan berubah. Dengan berlandaskan fungsi sebagai kaliffah maka dakam berbisnispun maka tujuan utamanya tidak hanya melulu mencari keuntungan tetapi lebih utama pada mencapai kemakmuran bersama dengan mengetenghkan praktekpraktek yang saling menguntungkan, tidak merugikan pihak lain dan tidak merugikan lama sekitarnya sesuai dengan perintah Allah SWt yang tercantum dalam Al Qur'an serta meniatkan semua aktifitasnya sebagai ibadah kepada Allah SWt dan mengharapkan ridha Allah SWT. 
IJVENTORY

Jurnal Akuntansi, Prodi. Akuntansi-FEB, UNIPMA, Vol. 1, No.2, April 2018

Perubahan konsep Corporate

Social Responsibility ini pada akhirnya akan membawa dampak yang sangat besar dalam implementasi Corporate Social Responsibility oleh perusahaan. Pemerintah tidak lagi perlu untuk mengatur secara tegas. Karena dengan munculnya kesadaran baru dalam konsep Corporate Social Responsibility yang berlandaskan pada singgle bottom line ini maka tanggu jawab perusahaan akan secara nyata dan sadar akan melakukan praktek bisnis khususnya Corporate Social Responsibility yang mengacu pada Khalifatullahu Fil Ardl.

\section{DAFTAR PUSTAKA}

Abdillah, Mujiyono. 2001. Agama Ramah Lingkungan; Perspektif al Qur'an. Paramadina. Jakarta

Al Qur'an

al Maududi, Abu A'la. 1994. Khilafah dan Kerajaan; Evaluasi Kritis atas Sejarah Pemerintahan Islam. Mizan. Bandung

Aminah, Wiwin Siti, Haryandi, dan Alfred Benedictus (ed). 2005.
Sejarah, Teologi, dan Etika Agama-agama .

Dian/Interfidei. Yogyakarta Carroll,AB.1979.AThreeDimensiona 1ConceptualModelofCorporat ePerformance.TheAcademyof Managementreview.Vol.4.No .4.October.Pp.497-525.

Carroll, AB. 1991. The Pyramid of Corporate Social Responsibility: Toward theMoralManagement

Capra, Fritjof. 2005. The Hidden Connections; Strategi Sistemik Melawan Kapitalisme Baru. Jalasutra. Yogyakarta

Chittick, William C. 2001. Dunia Imajinal Ibnu 'Arabi; Kreativitas Imajinasi dan Persoalan Diversitas Agama. Risalah Gusti. Surabaya.

CommitteeforEconomicDevelopment ,Social Responsibilities ofBusinessCorporations (NewYork: CED, 1971).ManagementRevi ew.2.3. Pp.70-76.

Ebiringa, O.T., E. Yadirichukwu, E.E. Chigbu dan O.J. Ogochukwu. 2013. Effect of 
INVENTORY

Jurnal Akuntansi, Prodi. Akuntansi-FEB, UNIPMA, Vol. 1, No.2, April 2018

Firm Size and Profitability

On Corporate Social

Responsibility Disclosure:

The Nigerian Oil an Gas

Sector In Focus. British

Journal of Economics,

Management \& Trade 3(4) :

$563-574,2013$

Environmental Milestone oleh

Worldwatch Institute dapat diakses pada alamat:

http://www.worldwatch.org/b

rain/features/timeline/timelin

e.htm

Gonick, Larry dan Alice Outwater.

2004. Kartun Lingkungan.

Kepustakaan Populer

Gramedia. Jakarta

Khilafah dan Kerajaan; Evaluasi

Kritis atas Sejarah

Pemerintahan Islam. Mizan.

Bandung

Kattsoff, Louis O. (2004). Pengantar

Filsafat. Yogyakarta: Tiara

Wacana

Yogya,

diterjemahkan oleh Soejono

Soemargono.

Lako, Andreas. 2011. Dekonstruksi

CSR dan Reformasi

Paradigma Bisnis \&

Akuntansi. Jakarta : Erlangga
Machfoedz, M. , (1999), Persepsi

Akuntan dan Mahasiswa tentang Etika Bisnis, Jurnal Riset Akuntansi Indonesia, Vol 2. No.1.Hal 1-19.

Nasution, Harun. 2006. Teologi Islam; Aliran-aliran Sejarah Analisa Perbandingan. Penerbit Universitas Indonesia. Jakarta

Nur, Marzully dan Denies Priantinah. 2012. Analisis Faktor - Faktor yang Mempengaruhi

Pengungkapan Corporate Social Responsibility di Indonesia (Studi Empiris Pada Perusahaan Berkategori High Profile yang Listing di Bursa Efek Indonesia). Jurnal Nominal/ Volume 1 Nomor 1/ Tahun 2012

Odum, Eugene P. 1971. Fundamentals of Ecology. W. B. Saunders Company. Philadelphia

Press Release tentang laporan UNEP tahun 2002 (GEO 3) dapat dilihat pada alamat: 
IJVENTORY

Jurnal Akuntansi, Prodi. Akuntansi - FEB, UNIPMA, Vol. 1, No.2, April 2018

http://www.grid.unep.ch/geo/

press.htm

Shihab, Quraish. 2005. Tafsir al Misbah; Pesan, Kesan, dan

Keserasian al Qur'an.

Lentera Hati. Jakarta

Soemarwoto, Otto. 1997. Ekologi, Lingkungan Hidup dan

Pembangunan. Djambatan.

Jakarta

Suttipun, M. dan P. Stanton. 2012.

Determinants

of

Environmental Disclosure In

Thai Corporate Annual

Reports. International

Tanudjaja,

B.B.

2009.

Perkembangan Corporate

Social Responsibility di

Indonesia. Universitas

Kristen Petra Surabaya

Tucker, Mary Evelyn dan John A

Grim (ed). 2003. Agama,

Filsafat, dan Lingkungan

Hidup. Kanisius. Yogyakarta

W Weiss, J 2009, Business Ethics: A

Stakeholder and Issues

Management approach, fifth edtion, south western-canggage learning, USA

Witteven, H J. 2004. Tasawuf in Action; Spiritualisasi Diri di
Dunia yang Tak Lagi Ramah.

Serambi. Jakarta

Zaenuddin, Achmad. 2007. FaktorFaktor yang Berpengaruh Terhadap Praktek Pengungkapan Sosial dan Lingkungan pada Perusahaan Manufaktur Go Publik. Tesis Universitas Diponegoro

Zakiah Daradjat, dkk, 1986, DasarDasar Agama Islam, Jakarta.

www.liputan6.com

www.merdeka.com

www.pekanbaru.tribunnews.com 